\title{
Are children's stools in Ghana disposed of safely? Evidence from the 2014 Ghana demographic and health survey
}

\author{
Abdul-Aziz Seidu ${ }^{1,2}$ (1)
}

\begin{abstract}
Background: Safe disposal of children's faeces has always been one of the main challenges to good hygiene in Ghana. Although it has been proven that children's faeces are more likely to spread diseases than adults' faeces, people usually mistake them for harmlessness. This study, therefore, sought to determine the prevalence and factors associated with safe disposal of children's faeces in Ghana.
\end{abstract}

Methods: Data from the 2014 Ghana Demographic and Health Survey was used for the analysis. A sample size of 2228 mother-child pairs were used for the study. The outcome variable was disposal of children stools. Both bivariate and multivariable logistic regression analyses were performed to identify the factors with safe child stool disposal.

Results: The prevalence of safe child stool disposal in Ghana was 24.5\%. Women in the middle [Adjusted odds ratio $(\mathrm{AOR})=4.62$; Confidence Interval $(\mathrm{Cl})=3.00-7.10]$, Coastal Zone $[\mathrm{AOR}=4.52 ; \mathrm{Cl}=2.82-7.22]$, mothers whose children were aged 12-17 [AOR $=1.56 ; \mathrm{Cl}=1.15-2.13]$ and 18-23 months $[\mathrm{AOR}=1.75 ; \mathrm{Cl}=1.29-2.39]$, and mothers whose household had improved type of toilet facility $[\mathrm{AOR}=2.04 ; \mathrm{Cl}=1.53-2.73]$ had higher odds of practicing safe children's faeces disposal. However, women from households with access to improved source of drinking water $[\mathrm{AOR}=0.62 ; \mathrm{Cl}=$ 0.45-2.7] had lower odds of practicing safe children's faeces disposal.

Conclusion: Approximately only about 25 out of 100 women practice safe disposal of their children's faeces in Ghana. The age of the child, ecological zone, the type of toilet facilities, and the type of drinking water source are associated with the disposal of child faeces. These findings have proven that only improved sanitation (i.e. drinking water and toilet facilities) are not enough for women to safely dispose of their children's faeces. Therefore, in addition to provision of toilet facilities especially in the northern zone of Ghana, there is also the need to motivate and educate mothers on safe disposal of children's stools especially those with children below 12 months. More so, mothers without access to improved toilet facility should also be educated on the appropriate ways to bury their children's stools safely.

Keywords: Children, DHS, Ghana, Public Health, Stool disposal

\footnotetext{
Correspondence: abdul-aziz.seidu@stu.ucc.edu.gh

'Department of Population and Health, College of Humanities and Legal

Studies, University of Cape Coast, Cape Coast, Ghana

${ }^{2}$ College of Public Health, Medical and Veterinary Sciences, James Cook

University, Townsville, Queensland, Australia
}

(c) The Author(s). 2021 Open Access This article is licensed under a Creative Commons Attribution 4.0 International License, which permits use, sharing, adaptation, distribution and reproduction in any medium or format, as long as you give appropriate credit to the original author(s) and the source, provide a link to the Creative Commons licence, and indicate if changes were made. The images or other third party material in this article are included in the article's Creative Commons licence, unless indicated otherwise in a credit line to the material. If material is not included in the article's Creative Commons licence and your intended use is not permitted by statutory regulation or exceeds the permitted use, you will need to obtain permission directly from the copyright holder. To view a copy of this licence, visit http://creativecommons.org/licenses/by/4.0/. The Creative Commons Public Domain Dedication waiver (http://creativecommons.org/publicdomain/zero/1.0/) applies to the data made available in this article, unless otherwise stated in a credit line to the data. 


\section{Background}

Access to improved sanitation remains one of the key public health issues in the global agenda, as stipulated in the Sustainable Development Goals (SDGs). For example, Goal 6.2 aims that there is universal access to appropriate sanitation and to end open defecation by 2025 [1]. The World Health Organization (WHO) points out that approximately 1 billion and 2.4 billion people respectively defecate in the open and live without improved sanitation facilities [2]. From these figures, approximately 842,000 people die from health-related diseases each year. Especially in Africa and Ghana, deaths of children under five account for 16 and $25 \%$ of diarrhoeal diseases, respectively [3]. In sub-Saharan Africa (SSA), approximately 229 million people engage in open defecation [4]. Approximately, only $21 \%$ of the population have access to basic sanitation facilities in Ghana (17\% for the rural population and $25 \%$ for the urban population) [5]. It is estimated that due to poor sanitation, Ghana loses about 1.6\% each year, equivalent to US\$290 million of our gross domestic product [5].

In many low- and middle-income countries [LMICs], how to deal with child faeces has always been a problem. It has also received less attention on the agenda of many governments [6-9]. In addition, there is a misunderstanding that children's faeces are harmless, so most parents dispose of their children's faeces unsafely $[9,10]$. Nevertheless, there is evidence that children's stools may be at higher risk than adults' stools, partly because of the presence of diarrhoea and pathogens such as hepatitis A, rotavirus, and E. coli. Similarly, children are also severely affected by enteric pathogens, making their stool the main source of infection $[8,11]$. Like many LMICs, in Ghana, poor sanitation is one of the main causes of faecal-oral diseases [12, 13].

Evidence again shows that children with unsafe stools are more likely to develop diarrhoea $[8,10]$. Based on these substantiations, safe disposal of faeces from children and adults is essential to prevent infection $[7,8,10$, 11, 14-17]. The prevalence of safe disposal of child faeces is $17 \%$ in Zimbabwe [18], 19.7\% in Nigeria [19], $21.0-27.5 \%$ in India $[8,18,20]$, and $[33.7-36.9 \%$ in Ethiopia [7, 11]. The prevalence is also $38.0 \%$ in Madagascar, $67.0 \%$ in Zambia, $70 \%$ in Kenya, $75 \%$ in Uganda, and $79 \%$ in Malawi [21]. The safe disposal of child faeces is associated with many factors. These include wealth $[7,11]$, child' sex, child's age $[7,11]$, family size [7], parity, sex of the head of the household [8], mother's age [11], educational level [7, 8, 19], ecological zone, place of residence $[8,11,22]$, ethnicity [8], religion, work status or employment, mother's exposure to the mass media, the child's diarrhoea experience [8], ANC attendance, type of toilet facility $[7,8]$, and source of drinking water $[7,8,19]$.
A report by the 2014 Demographic and Health Survey (GDHS) showed that nearly half (47\%) of mothers dispose of their children's faeces by throwing them into the garbage [23]. A small part of the population of Ghana has access to improved toilet facilities [23]. Based on these statistics, greater efforts are needed to strengthen existing strategies aimed at improving health conditions in Ghana. For example, the Ghanaian government has formulated various regional and national policies to improve sanitation conditions. For instance, the "Sama Sama" project in the northern zone (the then Northern and Upper East Regions) signed the "Sanitation and Water for All" project. The government has also drafted various policy documents, including "Environmental Sanitation Policy" [24], "National Environmental Sanitation Strategy and Action Plan" [25] and "Strategic Environmental Sanitation Investment Plan" [26, 27] to help improve sanitation in Ghana.

Although Ghana has adopted many strategies and efforts to improve sanitation conditions, how these strategies affect all parts of the population seems to be unexplored. A typical example is how Ghanaian women dispose of the faeces of their children. This study is aware of the research gaps and uses nationally representative data to assess the prevalence and associated factors of the safe disposal of children's faeces by Ghanaian mothers. The results of this study can help formulate measures and strengthen existing policies to promote the safe disposal of children's faeces in Ghana.

\section{Methods}

\section{Description of the survey and sampling}

The 2014 edition of the GDHS data was used for this study. GDHS is a nationwide study covering 10 regions at the time, conducted every 5 years. The survey was executed by the Ghana Statistics Service (GSS) and Ghana Health Service (GHS). Inner City Fund International provided technical help through MEASURE DHS. The survey adopts a multi-sampling approach to select the respondents. Particularly, two stages are followed to sample the unit of analysis in the households. In the initial stage, clusters encompassing enumeration areas (EAs) delineated for the 2010 Population and Housing Census were selected from the then 10 administrative regions of Ghana, comprising both urban and rural areas ([23] p.317). Afterwards, households from each cluster are selected and women who fall within these households are interviewed. In the 2014 survey, a total of 9396 women were interviewed (97.3\% response rate). The survey provided the complete birth history of women and their children. The current study includes 2228 children under the age of 2 living with mothers in each household. Their mothers answered questions relating to how they dispose of their stools. The GDHS final report 
[23] provides detailed information on the method, pre-testing, on-site staff training, sampling design, and selection. The report is also available online for free from https://dhsprogram.com/publications/publicationFR307-DHS-Final-Reports.cfm. The study relied on the "Strengthening of Epidemiological Observational Research Report" (STROBE) statement in writing the manuscript (Table S1).

\section{Ascertainment of variables \\ Outcome variable}

Disposal of children's stool was the outcome variable. It was a binary variable categorised as "safe or unsafe" [7$9,11,18-20,28,29]$. It was derived from the question "The last time [Name] passed stools, what was done to dispose of the stools?" The response included the following: "child used the toilet or latrine," "put/rinsed into toilet or latrine," "put/rinsed into drain/ditch," "thrown into the garbage," "buried," "left in the open," and "other." The study followed the WHO's [2] definition of safe disposal of faeces as situations where child used toilet/latrine, put/rinsed faeces into the toilet or latrine and buried the faeces and unsafe stool disposal as situations where one put/rinsed faeces into drain or ditch, faeces thrown into the garbage, faeces left or unburied in the open. These responses were recoded as follows: all those who answered "child used toilet or latrine", buried and those who "put/rinsed into toilet or latrine" were merged and coded as "safe disposal of child stool" (coded as ' 1 ') whereas the remaining disposal practices were coded as "unsafe disposal of child stool" (coded as ' 0 ').

\section{Independent variables}

The independent variables were included based on their association with children's stool disposal in previous studies $[7-9,11,18-20,28,29]$. These variables were household wealth (poorest, poorer, middle, richer, richest), sex of child (male, female), age of the child (0-5 months, 6-11 months, $12-17$ months, $18-23$ months), number of people in household $(>5,<5)$, parity $(1,2,3$, $4+)$, sex of household head (male, female), mother's age (15-24, 25-34, > 34), mother's educational level (no education, primary, secondary/ higher), ecological zone (northern, middle, coastal), place of residence (urban, rural), ethnicity (Akan, Ga-Dangbe, Ewe, Mole Dagbani, Others), religion (Christianity, Islam, others), working status (not working, working), mother's exposure to mass media (newspaper, television, and radio [all captured as, not at all, less than once a week, at least once a week]), child experienced diarrhoea in the last 2 weeks (yes, no), and ANC attendance (none, 1-3 times, 4 or more times). In addition, the toilet facility used by members in the household and source of drinking water for members in the household were all categorized as improved' and 'unimproved' $[2,21]$.

\section{Statistical analyses}

The analysis of the data followed three key steps. First, the data were extracted from the children's file and cleaned. Afterwards, frequency counts and percentages were estimated for categorical variables. A chi-square analysis was done to show the factors associated with child stool disposal and those that showed statistical significance $(p<$ 0.05 ) were included in the regression analysis (see Table 1 ). At the regression analysis stage, both bivariate and multivariable logistic regression modelling were done and the results were presented as crude odds ratios (COR) and adjusted odds ratios (AOR) respectively with their corresponding 95\% confidence intervals (CI) signifying level of precision. Before carrying out the logistic regression analysis, multicollinearity was checked using the Variance Inflation Factor (VIF) (Mean VIF $=1.43$, Maximum VIF $=$ 2.35 and Minimum VIF =1.02). The choice of reference categories was also informed by previous studies and a priori. Sampling weight was assigned at various levels of analysis to account for over- and under-sampling of some areas within the study settings while the svy command was used to take account of the complex sampling procedure.

\section{Results \\ Weighted prevalence of youngest children's stool disposal in Ghana}

Figure 1 presents the weighted prevalence of stool disposal practices among women in Ghana. It was found that a quarter $(24.5 \%)$ had disposed of their children's stool safely while $2.4 \%$ indicated they disposed it of by using toilet or latrine.

\section{Prevalence of Child's stool disposal across independent variables among women in Ghana}

Table 1 also shows the background characteristics of the women. It was found that $49.8 \%$ were aged $25-34$. The majority $(63.8 \%)$ were married, $74.4 \%$ were Christians, $45.8 \%$ were Akans, approximately $23 \%$ were in the poorest wealth category, and $78.6 \%$ were working. Slightly more than half (54.0\%) had attained secondary/higher level of education. The majority (55.2\%) were also in rural areas while $38.8 \%$ had 4 or more children (Table 1 ).

Logistic regression results on factors associated with safe children's stool disposal among women in Ghana

It was found that women in the middle $[\mathrm{AOR}=4.62$; $\mathrm{CI}=3.00-7.10]$ and coastal zone $[\mathrm{AOR}=4.52 ; \mathrm{CI}=$ 2.82-7.22] had higher odds of practising safe disposal of their children stool, compared to those in the northern zone. The odds of practicing safe child faeces disposal was higher for mothers whose children were aged 12-17 
Table 1 Selected socio-demographic characteristics and prevalence of Child's stool disposal across independent variables among women in Ghana ( $N=2228)$

\begin{tabular}{|c|c|c|c|c|}
\hline \multirow[t]{2}{*}{ Variables } & \multicolumn{2}{|c|}{ Weighted sample } & \multirow[t]{2}{*}{ Safe } & \multirow[t]{2}{*}{$P$-values } \\
\hline & $\mathrm{N}$ & $\%$ & & \\
\hline Age & & & & $p=0.0856$ \\
\hline $15-24$ & 568 & 25.5 & 22.1 & \\
\hline $25-34$ & 1110 & 49.8 & 23.2 & \\
\hline $35-49$ & 550 & 24.7 & 22.5 & \\
\hline Marital status & & & & $p=0.009$ \\
\hline Not Married & 807 & 36.2 & 26.1 & \\
\hline Married & 1421 & 63.8 & 21.1 & \\
\hline Religion & & & & $P<0.001$ \\
\hline Christianity & 1659 & 74.4 & 26.0 & \\
\hline Islam & 398 & 17.9 & 14.6 & \\
\hline Other & 171 & 7.7 & 15.8 & \\
\hline Ethnicity & & & & $p<0.001$ \\
\hline Akan & 1021 & 45.8 & 33.1 & \\
\hline Ga-Dangbme & 131 & 5.9 & 26.5 & \\
\hline Ewe & 295 & 13.2 & 30.4 & \\
\hline Mole-Dagbani & 429 & 19.3 & 13.5 & \\
\hline Others & 352 & 15.8 & 11.6 & \\
\hline Wealth & & & & $p<0.001$ \\
\hline Poorest & 506 & 22.7 & 11.6 & \\
\hline Poorer & 466 & 20.9 & 29.3 & \\
\hline Middle & 434 & 19.5 & 28.2 & \\
\hline Richer & 432 & 19.4 & 28.8 & \\
\hline Richest & 391 & 17.5 & 25.8 & \\
\hline Residence & & & & $p=0.756$ \\
\hline Rural & 1229 & 55.2 & 22.5 & \\
\hline Urban & 999 & 44.9 & 23.1 & \\
\hline Ecological zone & & & & $p<0.001$ \\
\hline Northern & 451 & 20.2 & 6.5 & \\
\hline Coastal & 801 & 36.0 & 31.9 & \\
\hline Middle & 976 & 43.8 & 31.0 & \\
\hline Educational level & & & & $p<0.001$ \\
\hline No education & 605 & 27.2 & 14.1 & \\
\hline Primary & 420 & 18.8 & 22.4 & \\
\hline Secondary/higher & 1203 & 54.0 & 29.4 & \\
\hline Working status & & & & $p=0.032$ \\
\hline Not working & 477 & 21.4 & 26.4 & \\
\hline Working & 1751 & 78.6 & 21.8 & \\
\hline Frequency of reading newspaper & & & & $P=0.357$ \\
\hline Not at all & 1965 & 88.3 & 22.3 & \\
\hline Less than once a week & 142 & 6.4 & 27.6 & \\
\hline At least once a week & 119 & 5.4 & 24.7 & \\
\hline Frequency of listening to radio & & & & $p=0.004$ \\
\hline
\end{tabular}


Table 1 Selected socio-demographic characteristics and prevalence of Child's stool disposal across independent variables among women in Ghana ( $N=2228)$ (Continued)

\begin{tabular}{|c|c|c|c|c|}
\hline \multirow[t]{2}{*}{ Variables } & \multicolumn{2}{|c|}{ Weighted sample } & \multirow[t]{2}{*}{ Safe } & \multirow[t]{2}{*}{$P$-values } \\
\hline & $\mathrm{N}$ & $\%$ & & \\
\hline Not at all & 673 & 30.2 & 19.2 & \\
\hline Less than once a week & 553 & 24.8 & 26.2 & \\
\hline At least once a week & 1002 & 45.0 & 24.4 & \\
\hline Frequency of watching television & & & & $p<0.001$ \\
\hline Not at all & 403 & 18.1 & 16.0 & \\
\hline Less than once a week & 743 & 33.3 & 26.7 & \\
\hline At least once a week & 1082 & 48.6 & 23.0 & \\
\hline ANC attendance & & & & $p=0.097$ \\
\hline 0 & 65 & 3.0 & 13.3 & \\
\hline $1-3$ & 242 & 11.2 & 20.8 & \\
\hline $4+$ & 1860 & 85.9 & 23.3 & \\
\hline Household head sex & & & & $p=0.011$ \\
\hline Male & 1717 & 77.1 & 21.6 & \\
\hline Female & 511 & 22.9 & 27.1 & \\
\hline Parity & & & & $P=0.336$ \\
\hline 1 & 474 & 21.3 & 20.9 & \\
\hline 2 & 487 & 21.9 & 25.8 & \\
\hline 3 & 403 & 18.1 & 21.9 & \\
\hline $4+$ & 864 & 38.8 & 22.6 & \\
\hline Child had diarrhoea & & & & $p=0.302$ \\
\hline No & 1929 & 86.6 & 23.1 & \\
\hline Yes & 299 & 13.4 & 20.5 & \\
\hline Sex of child & & & & $p=0.141$ \\
\hline Male & 1172 & 52.6 & 21.5 & \\
\hline Female & 1056 & 47.4 & 24.1 & \\
\hline Child's age (months) & & & & $p<0.001$ \\
\hline $0-5$ & 545 & 24.5 & 17.5 & \\
\hline $6-11$ & 586 & 26.3 & 20.5 & \\
\hline $12-17$ & 565 & 25.3 & 25.1 & \\
\hline $18-23$ & 533 & 23.9 & 28.7 & \\
\hline Number of household members & & & & $P=0.106$ \\
\hline$<5$ & 1290 & 57.9 & 24.1 & \\
\hline$>5$ & 938 & 42.1 & 21.2 & \\
\hline Source of drinking water & & & & $p<0.001$ \\
\hline Unimproved & 293 & 13.2 & 11.9 & \\
\hline Improved & 1935 & 86.8 & 30.7 & \\
\hline Access to toilet facility & & & & $p=0.028$ \\
\hline Unimproved & 771 & 34.6 & 27.3 & \\
\hline Improved & 1457 & 65.4 & 21.9 & \\
\hline
\end{tabular}

Source: 2014 GDHS 


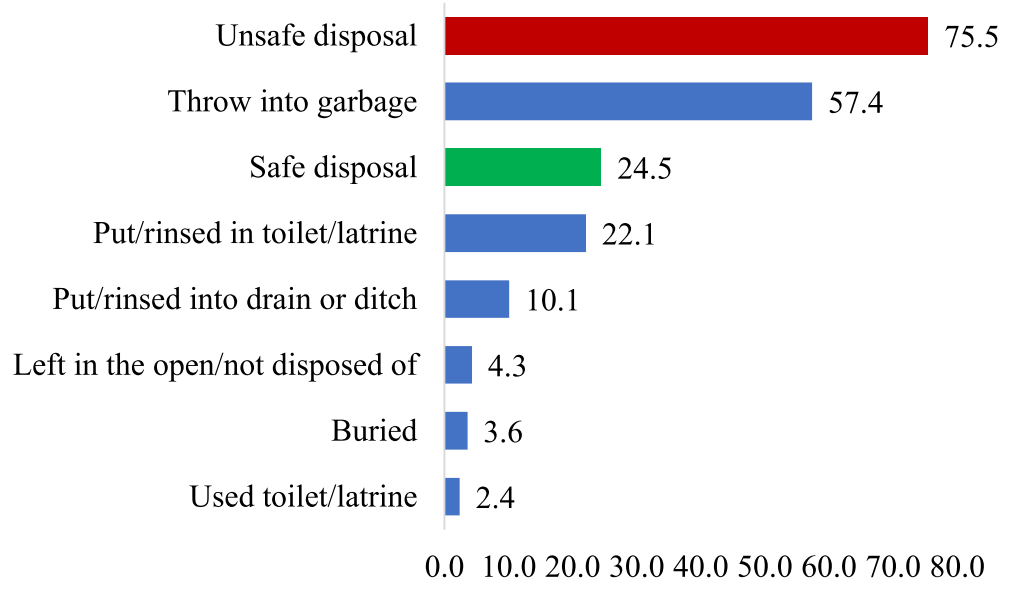

Fig. 1 Weighted prevalence of youngest children's stool disposal in Ghana $(N=2228)$

[AOR = 1.56; $\mathrm{CI}=1.15-2.13]$ and 18-23 months $[\mathrm{AOR}=$ $1.75 ; \mathrm{CI}=1.29-2.39]$, compared to those whose children are less than 6 months. It was also found that mothers whose household had improved type of toilet facility $[\mathrm{AOR}=2.04 ; \mathrm{CI}=1.53-2.73]$ had higher odds of practicing safe child faeces disposal, compared to those with unimproved toilets. Finally, women from households with access to improved source of drinking water had lower odds $[\mathrm{AOR}=0.62 ; \mathrm{CI}=0.45-0.85]$ of practicing safe child faeces disposal, compared to those who had unimproved source of drinking water (Table 2).

\section{Discussion}

\section{Summary of key findings}

This study aimed to assess the prevalence and factors associated with safe disposal of children's faeces in Ghana. It is probably the first in Ghana that seeks to provide evidence on this phenomenon, using nationally representative data. A quarter $(24.5 \%)$ of women in Ghana dispose of their children's faeces safely. The study also found that the type of toilet facilities, the source of drinking water, the age of the child, and ecological zone are the main factors associated with the disposal of children's faeces. The results of this study are important in Ghana and other low- and middle-income countries with poor sanitation.

\section{Syntheses with previous evidence}

In this study, the prevalence of safe disposal of children's faeces (24.5\%) is similar to results obtained in Bangladesh [28] and India [8, 19, 20] but slightly higher than Zimbabwe [18] and Nigeria [9]. However, it is lower than what is reported in Ethiopia [7, 11], Madagascar [21], Zambia, Kenya, Uganda, Malawi [21], and Nepal [21]. Unsafe disposal of child faeces is more likely to expose children and people around them to various health problems through various mechanisms [11]. Some studies have reported that there is a significant association between unsafe child stool disposal and diarrhoea, soil-borne worm infections, trachoma, and other intestinal diseases [2, 14]. For example, Bawankule et al. [8] revealed that in India, children whose stools were disposed unsafely stood greater chances of suffering from diarrhoea.

Compared with mothers with children 0-5 months old, mothers with children 12 months and older are more likely to safely dispose of their children's faeces. This result confirms earlier studies in Bangladesh [20, 30] and Ethiopia [7, 11]. Various explanations have been proposed for this association. For example, it has been explained that mothers might think that the faeces of young children are harmless, small, smell less, have fewer visible food residues, and are therefore less disgusting than faeces of adults [10,30-32]. Another explanation is that as children grow up, they will receive instructions on how to use the toilet by themselves, instead of having their mothers dispose of the faeces [11, 21]. It is, therefore, imperative for community health nurses to educate mothers on the importance of disposing of children's stools safely irrespective of the child's age by paying particular attention to those whose children are less than 12 months.

Ecological zone was significantly associated with the disposal of child faeces. It was found that compared with the northern zone (Upper East, Upper West, and Northern Regions at the time), child faeces in the coastal and central zones were more likely to be safely disposed of. This means that mothers in the northern zone are more likely to unsafely dispose of their children's faeces. Compared with the central and coastal zones, the northern region is dominated by a large number of rural communities. The results can be discussed in the context of the available toilet facilities and the socio-cultural practices surrounding toilet use and the disposal of children's stools [33], as well as the differences in the disposal of 
Table 2 Factors associated with safe child stool disposal among women in Ghana

\begin{tabular}{|c|c|c|c|c|c|c|}
\hline \multirow[t]{2}{*}{ Variables } & \multirow[t]{2}{*}{ COR } & \multicolumn{2}{|l|}{$95 \% \mathrm{Cl}$} & \multirow[t]{2}{*}{ AOR } & \multicolumn{2}{|c|}{$95 \% \mathrm{Cl}$} \\
\hline & & Lower & Upper & & Lower & Uppe \\
\hline \multicolumn{7}{|l|}{ Marital status } \\
\hline Not Married & Ref & Ref & Ref & Ref & Ref & Ref \\
\hline Married & $*^{* *} 0.76$ & 0.62 & 0.93 & 1.12 & 0.88 & 1.43 \\
\hline \multicolumn{7}{|l|}{ Religion } \\
\hline Christianity & Ref & & & Ref & & \\
\hline Islam & ${ }^{* * *} 0.49$ & 0.37 & 0.64 & 0.92 & 0.64 & 1.32 \\
\hline other & $* * * 0.53$ & 0.36 & 0.79 & 1.15 & 0.74 & 1.79 \\
\hline \multicolumn{7}{|l|}{ Ethnicity } \\
\hline Akan & Ref & Ref & Ref & Ref & Ref & Ref \\
\hline Ga-Dangbme & 0.73 & 0.45 & 1.17 & 0.81 & 0.50 & 1.3 \\
\hline Ewe & 0.88 & 0.65 & 1.20 & 0.89 & 0.64 & 1.24 \\
\hline Mole-Dagbani & ${ }^{* * *} 0.31$ & 0.24 & 0.41 & 1.08 & 0.72 & 1.62 \\
\hline Others & ${ }^{* * *} 0.26$ & 0.19 & 0.37 & 0.68 & 0.44 & 1.03 \\
\hline \multicolumn{7}{|l|}{ Wealth status } \\
\hline Poorest & Ref & Ref & Ref & Ref & Ref & Ref \\
\hline Poorer & $* * * 3.17$ & 2.35 & 4.28 & 1.17 & 0.80 & 1.7 \\
\hline Middle & $* * * 3.01$ & 2.19 & 4.12 & 1.02 & 0.66 & 1.58 \\
\hline Richer & $* * * 3.10$ & 2.24 & 4.29 & 1.00 & 0.62 & 1.61 \\
\hline Richest & $* * * 2.66$ & 1.87 & 3.79 & 0.72 & 0.43 & 1.22 \\
\hline
\end{tabular}

\section{Educational level}

No education
Primary
Secondary/higher

\section{Working status}

Not working

Working

\section{Ecological Zone}

Northern

Coastal

Middle

Frequency of watching television

Not at all

Less than once a week

At least once a week

Frequency of listening radio

$$
\begin{aligned}
& \text { Not at all } \\
& \text { Less than once a week } \\
& \text { At least once a week }
\end{aligned}
$$

Sex of Household head

Male

Child's age

0-5
Ref

***1.76

***2.54

Ref

${ }^{*} 0.78$

Ref

${ }^{* * *} 6.77$

***6.49

Ref

**1.495

**1.36

Ref

**1.91

**1.57

Ref

*1.35

Ref
Ref

1.30

1.99

Ref

0.61

Ref

4.85

4.71

Ref

1.15

1.08

\section{Ref}

1.41

1.17

Ref

1.07

Ref

\section{Ref}

2.38

3.24

Ref

0.98

Ref

9.45

8.95

\section{Ref}

1.95

1.71

Ref

2.59

2.10

Ref

1.71

Ref
Ref

1.01

1.24

Ref

0.80

Ref

***4.52

***4.62

Ref

0.79

0.87

Ref

1.32

1.12

Ref

1.02

Ref
Ref

0.71

0.88

Ref

0.62

Ref

2.82

3.00

Ref

0.57

0.63

Ref

0.94

0.80

Ref

0.78

Ref

1.33
.32

f

7

.58

1.22

Ref

1.44

1.76

Ref

1.03

Ref

7.22

7.10

Ref

1.10

1.20

Ref

1.87

1.56 
Table 2 Factors associated with safe child stool disposal among women in Ghana (Continued)

\begin{tabular}{|c|c|c|c|c|c|c|}
\hline \multirow[t]{2}{*}{ Variables } & \multirow[t]{2}{*}{ COR } & \multicolumn{2}{|l|}{$95 \% \mathrm{Cl}$} & \multirow[t]{2}{*}{ AOR } & \multicolumn{2}{|l|}{$95 \% \mathrm{Cl}$} \\
\hline & & Lower & Upper & & Lower & Upper \\
\hline $6-11$ & 1.21 & 0.90 & 1.63 & 1.06 & 0.77 & 1.46 \\
\hline $12-17$ & $* * 1.58$ & 1.18 & 2.10 & $* * 1.56$ & 1.15 & 2.13 \\
\hline $18-23$ & $* * * 1.90$ & 1.43 & 2.53 & $* * * 1.75$ & 1.29 & 2.39 \\
\hline \multicolumn{7}{|c|}{ Type of toilet facility } \\
\hline Unimproved & Ref & Ref & Ref & Ref & Ref & Ref \\
\hline Improved & $* * * 3.28$ & 2.61 & 4.14 & $* * 2.04$ & 1.53 & 2.73 \\
\hline \multicolumn{7}{|c|}{ Source of drinking water } \\
\hline Unimproved & Ref & Ref & Ref & Ref & Ref & Ref \\
\hline Improved & ${ }^{*} 0.75$ & 0.58 & 0.97 & $* * 0.62$ & 0.45 & 0.85 \\
\hline Pseudo $R^{2}$ & & & & & & 0.12 \\
\hline $\mathbf{N}$ & & & & & & 2228 \\
\hline
\end{tabular}

${ }^{*} p<0.05,{ }^{* *} p<0.01,{ }^{* * *} p<0.001$

COR Crude Odds Ratio, AOR Adjusted Odds Ratio, Cl Confidence Interval, Ref reference category Source: 2014 GDHS

rural and urban children stools as reported in the GDHS report [23], Ethiopia [7, 11], and Kenya [34].

According to data from the World Health Organization [2], in Africa, Ghana is the second-largest open defecation country after Sudan. About 5 million Ghanaians do not have toilet facilities. In 2015, the World Bank also estimated that $18.75 \%$ of Ghanaians practice open defecation, which is the most common practice in the northern zone [35]. For example, 89,72 , and $71 \%$ of the population in the Upper East Region, North Region, and Upper West Region have no toilet facilities, respectively $[2,33]$, and most resort to using bushes, fields, or small containers for defecation [33, 36]. In most of these circumstances, children are those who practice open defecation the most since some toilet facilities are originally not designed to easily support their usage [33]. In Ghana, there is an urban-rural gap in sanitation coverage, toilet facilities, and access to safe drinking water. In most cases, some families across the country conform to social norms, beliefs, and expectations regarding hygiene behavioor [22, 33]. For example, Osumanu, Kosoe, and Ategeeng ([33], p.7) found in the northern region (Wa) that people firmly believe that "witches, wizards, and other bad spirits visit the toilet at night and as such woe unto anybody who is spotted by these spirits around those hours in the toilet". This belief may also prevent mothers from practicing safe disposal of their children's faeces. Therefore, it is necessary to conduct community publicity through various platforms such as community information centers and social gatherings to educate people about the importance of safe disposal of child faeces.

Another important finding of this study is that mothers with improved toilet facilities in their households are more likely to safely dispose of their children's faeces. Previous studies in Ethiopia [7], India [8], South Africa [37], and Bangladesh [28] also reported similar findings. As described by Majorin et al. [20], families with toilets are more likely to adopt safer methods of disposing children's faeces. This is also supported by Sara and Graham [37], who explained that ownership of physical infrastructure of improved sanitation can motivate people to adopt safe hygienic practices. There is, therefore, the need to institute various measures to ensure improvement in the type of toilet facilities in various households.

Similar to previous studies in Ethiopia [7, 11], this study also did not find a statistically significant association with diarrhoea and unsafe disposal of children's stool disposal. However, there is no information on the frequency of diarrhoea and how easily the questions asked have any connection to unsafe handling. However, unlike previous studies $[7,8,11,20]$, this study found a statistically significant association between the type of drinking water source and the disposal of children's faeces. Specifically, this study found the opposite relationship, that is, mothers in families with improved water sources are less likely to practice safe disposal of child faeces. This finding contradicts the previous study by Curtis et al. [22]. Possible differences in research results may be variables used to measure the type of water source, differences in settings, and differences in research time. Nevertheless, different types of research designs and methods (such as case-controlled studies or qualitative studies) must be used to clarify these nuances.

\section{Strength and limitations}

The main strength of this study is the use of nationally representative survey data with a relatively large sample size. In this way, it is possible to generalise the findings 
to women with children under 2 years in Ghana and other geographical locations with similar characteristics. Nevertheless, this study is a cross-sectional study, so it cannot be claimed that the findings obtained have any causal relationship. The outcome variable, the disposal of child faeces, was collected based on reported practice rather than direct observation. Nevertheless, Clarkson et al. [38] found that direct observation is full of Hawthorne effect, so people tend to change their behaviour because they know they are being investigated. There is also the possibility of social desirability and recall bias. However, recall bias is likely to be minimal, given that mothers were asked the question "the last time [NAME] passed stools, what was done to dispose of the stools?" rather than the usual practice of disposal of stools. Finally, there is the possibility of missing some key variables including hand washing and soap use.

\section{Conclusion}

This study shows that only a quarter of women safely dispose of their children's faeces. The age of the child, ecological zone, the type of toilet facilities, and the type of drinking water source are associated with the safe disposal of child faeces. This finding proves that just getting improved sanitation (such as drinking water and toilet facilities) is not enough for women to safely dispose of their children's faeces. In addition to providing toilet facilities in northern Ghana, health practitioners also need to motivate and educate mothers on how to safely handle children's faeces, especially mothers with children under 12 months of age. More so, mothers who do not have access to improved toilet facilities must be informed on the safe disposal of their children's stools. Future studies could look at the disposal practices in the various ecological zones in Ghana, taking into consideration the rural urban divisions as well as the trend of safe disposal practices in Ghana. Qualitave studies are also needed to gain deeper understanding of the reasons why women dispose of their children's stools unsafely.

\section{Supplementary Information}

The online version contains supplementary material available at https://doi. org/10.1186/s12889-021-10155-7.

Additional file 1: Table S1. STROBE 2007 (v4) Statement-Checklist of items that should be included in reports of cross-sectional studies.

\footnotetext{
Abbreviations

COR: Crude Adjusted Odds Ratio; AOR: Adjusted Odds Ratio; Cl: Confidence Interval; GDHS: Ghana Demographic and Health Survey; SDG: Sustainable Development Goal; WHO: World Health Organisation; SSA: Sub-Saharan Africa; LMICs: Low- and middle-income countries; MLGRD: Ministry of Local Government and Rural Development; GSS: Ghana Statistical Service; GHS: Ghana Health Service; EAs: Enumeration areas; VIF: Variance Inflation Factor
}

\section{Acknowledgments}

I am grateful to Measure DHS for giving me access to the data. I also appreciate the effort of Mr. Ebenezer Agbaglo, a budding linguist in the Department of English, University of Cape Coast, who took the pain to copyedit this manuscript.

\section{Author's contributions}

Conception and design of study: AS; analysis and/or interpretation of data: AS; drafting the manuscript: AS; revising the manuscript critically for important intellectual content; AS; proofreading of manuscript; AS. have read and approved the final manuscript for submission.

\section{Funding}

The study did not receive any funding.

\section{Availability of data and materials}

Dataset is publicly available via this link https://dhsprogram.com/data/ dataset/Ghana_Standard-DHS_2014.cfm?flag=0

\section{Ethics approval and consent to participate}

Institutional review board of the Ghana Health Service and the ethics committee of the DHS Program approved the survey. Informed consent was obtained from all the respondents before the commencement of interviews with each respondent. Further information about the DHS data usage and ethical standards are available at http://goo.gl/ny8T6X.

\section{Consent for publication}

Not applicable.

\section{Competing interests}

The author (s) declare that they have no competing interests. Abdul-Aziz Seidu is a member of the Editorial Board.

Received: 31 March 2020 Accepted: 1 January 2021

Published online: 09 January 2021

\section{References}

1. United Nations. Transforming our world: the 2030 agenda for sustainable development. Resolution adopted by the General Assembly, vol. 25; 2015.

2. WHO Fact Sheet on Sanitation 2020.World Health Organization, Geneva, Switzerland. http://www.who.int/en/news-room/fact-sheets/detail/sanitation. Accessed 27 Mar 2020

3. Binka E, Vermund SH, Armah GE. Rotavirus as a cause of diarrhea among children under 5 years of age in urban Ghana: prevalence and serotypes/ genotypes. Pediatr Infect Dis J. 2011;30(8):718.

4. Amouzou A, Velez LC, Tarekegn H, Young M. One is too many: ending child deaths from pneumonia and diarrhoea; 2016.

5. WSP. Ghana loses GHC420 million annually due to poor sanitation. March: Economic Impacts of Poor Sanitation in Africa. Retrieved from: https://www. wsp.org/sites/wsp.org/ files/publications/WSP-ESI-Ghana-brochure.pdf. Accessed 27 Mar 2020

6. World Bank, Unicef. Child feces disposal in Madagascar: Available at http:// www.wsp.org/sites/wsp.org/files/publications/WSP-Madagascar- CFD-Profile. pdf. Accessed 27 Mar 2020.

7. Azage M, Haile D. Factors associated with safe child feces disposal practices in Ethiopia: evidence from demographic and health survey. Arch Public Health. 2015;73(1):40.

8. Bawankule R, Singh A, Kumar K, Pedgaonkar S. Disposal of children's stools and its association with childhood diarrhea in India. BMC Public Health. 2017;17(1):12

9. Aluko OO, Afolabi OT, Olaoye EA, Adebayo AD, Oyetola SO, Abegunde OO. The management of the faeces passed by under five children: an exploratory, cross-sectional research in an urban community in Southwest Nigeria. BMC Public Health. 2017;17(1):178.

10. Gil A, Lanata C, Kleinau E, Penny M. Children's feces disposal practices in developing countries and interventions to prevent diarrheal diseases; A literature review. Strategic report 11, Bureau for Global Health. Washington, DC 20523200.

11. Sahiledengle B. Prevalence and associated factors of safe and improved infant and young children stool disposal in Ethiopia: evidence from demographic and health survey. BMC Public Health. 2019;19(1):970. 
12. Gebru T, Taha M, Kassahun W. Risk factors of diarrhoeal disease in underfive children among health extension model and non-model families in Sheko district rural community. Southwest Ethiopia: comparative crosssectional study. BMC Public Health. 2014;14:395.

13. Anteneh ZA, Andargie K, Tarekegn M. Prevalence and determinants of acute diarrhea among children younger than five years old in Jabithennan District, Northwest Ethiopia, 2014. BMC Public Health. 2017;17(1):99.

14. Morita T, Godfrey S, George CM. Systematic review of evidence on the effectiveness of safe child faeces disposal interventions. Tropical Med Int Health. 2016;21(11):1403-19.

15. Rand EC, Loughnan EC, Maule L, Reese H. Management of child feces : Current disposal practices. Water and Sanitation Program research brief. Washington, D.C: World Bank Group; 2015

16. United Nations Children's Fund. Child feces disposal in Ethiopia; 2014. Available from: https://www.wsp.org/sites/wsp.org/files/publications/WSPEthiopia-CFD-Profile.pdf. Accessed on 1/3/2020.

17. World Health Organization \& United Nations Children's Fund ( UNICEF). Core questions on drinking water and sanitation for household surveys. 2006. World Health Organization. https://apps.who.int/iris/handle/10665/434 89. Accessed Mar 282020.

18. Demberere T, Chidziya T, Ncozana T, Manyeruke N. Knowledge and practices regarding water, sanitation and hygiene (WASH) among mothers of under-fives in Mawabeni, Umzingwane District of Zimbabwe. Physics Chem Earth, Parts A/B/C. 2016;92:119-24.

19. Preeti PS, Sahoo SK, Biswas D, Dasgupta A. Unsafe disposal of child Faeces: a community-based study in a rural block in West Bengal, India. J Prev Med Public Health. 2016;49(5):323-30.

20. Majorin F, Freeman MC, Barnard S, Routray P, Boisson S, Clasen T. Child feces disposal practices in rural Orissa: a cross sectional study. PLoS One. 2014;9(2):e89551.

21. WHO/UNICEF. Joint Water Supply Sanitation Monitoring Programme. Progress on drinking water and sanitation: 2014 Update. Geneva: World Health Organization; 2014.

22. Curtis V, Kanki B, Mertens T, Traore E, Diallo I, Tall F, Cousens S. Potties, pits and pipes: explaining hygiene behaviour in Burkina Faso. Soc Sci Med. 1995; 41(3):383-93.

23. Ghana Statistical Service, Ghana Health Service, ICF Macro International. Ghana demographic and health survey 2014. Accra: Key indicators GSS, GHS and ICF Macro; 2015. p.1-506.

24. MLGRD Guidelines for the provision, operation and maintenance Management of Public Toilets in Ghana. Ministry of Local Government and Rural Development, government of Ghana, Accra, Ghana.

25. MLGRD \& EHSD 2010. National Environmental Sanitation Strategy and Action Plan (NESSAP) 2010-2015. Ministry of Local Government and Rural Development \& Environmental Health and Sanitation Directorate, Accra. https://www.ircwash.org/sites/default/files/MLGRD-2010-National.pdf. Accessed 27 Mar 2020

26. WSP 2012 Ghana loses GHC420 million annually due to poor sanitation March: Economic Impacts of Poor Sanitation in Africa Retrieved from: https://www.wsp.org/sites/wsp.org/files/publications/WSP-ESI-Ghanabrochure.pdf. Accessed 27 Mar 2020.

27. Appiah-Effah E, Duku GA, Azangbego NY, Aggrey RKA, Gyapong-Korsah B, Nyarko KB. Ghana's post-MDGs sanitation situation: an overview. J Water Sanit Hyg Dev. 2019;9(3):397-415.

28. Islam M, Ercumen A, Ashraf S, Rahman M, Shoab AK, Luby SP, Unicomb L. Unsafe disposal of feces of children $<3$ years among households with latrine access in rural Bangladesh: association with household characteristics, fly presence and child diarrhea. PloS one. 2018;13(4): e0195218.

29. Ifezulike CC, Azikiwe CC, Modebe IA, Nwabueze SA, Amazu LU. Pattern of disposal of child faeces and other waste among community-directed distributors in Anambra east local government area, Anambra state, Southeast Nigeria. URJMMS. 2015;3(2):014-20.

30. Sultana R, Mondal UK, Rimi NA, Unicomb L, Winch PJ, Nahar N, Luby SP. An improved tool for household faeces management in rural Bangladeshi communities. Tropical Med Int Health. 2013 Jul;18(7):854-60.

31. Brown J, Cairncross S, Ensink JHJ. Water, sanitation, hygiene and enteric infections in children. Arch Dis Child. 2013;98(8):629-34.

32. Yeager BA, Huttly SR, Bartolini R, Rojas M, Lanata CF. Defecation practices of young children in a Peruvian shanty town. Soc Sci Med. 1999;49(4):531-41.
33. Osumanu IK, Kosoe EA, Ategeeng F. Determinants of open defecation in the Wa municipality of Ghana: empirical findings highlighting sociocultural and economic dynamics among households. J Environ Public Health. 2019;2019.

34. Demographic K. Health Survey 2008-09, Kenya National Bureau of Statistics (KNBS) and ICF Macro. Nairobi: KNBS and ICF macro; 2010.

35. World Bank. World development report 2015: mind, society, and behavior. Washington, DC: The World Bank; 2015.

36. Water Aid. Abandoning open defecation: comparison and Adoptation of social change dynamics. Accra: Water Aid Ghana; 2008.

37. Sara S, Graham J. Ending open defecation in rural Tanzania: which factors facilitate latrine adoption? Int J Environ Res Public Health. 2014;11(9):9854-70.

38. Clasen $T$, Boisson S, Routray P, Torondel B, Bell M, Cumming O, Ensink J, Freeman $M$, Jenkins $M$, Odagiri $M$, et al. Effectiveness of a rural sanitation programme on diarrhoea, soil-transmitted helminth infection, and child malnutrition in Odisha, India: a cluster-randomised trial. Lancet Glob Health. 2014;2(11):e645-53.

\section{Publisher's Note}

Springer Nature remains neutral with regard to jurisdictional claims in published maps and institutional affiliations.
Ready to submit your research? Choose BMC and benefit from:

- fast, convenient online submission

- thorough peer review by experienced researchers in your field

- rapid publication on acceptance

- support for research data, including large and complex data types

- gold Open Access which fosters wider collaboration and increased citations

- maximum visibility for your research: over $100 \mathrm{M}$ website views per year

At BMC, research is always in progress.

Learn more biomedcentral.com/submissions 